\title{
Academic performance in reading a text as related to course grades: Student performance when studying is impossible
}

\author{
RUSSELL EISENMAN, CAM L. MELVILLE, and CONNIE F. ST. ANDRIE \\ McNeese State University, Lake Charles, Louisiana
}

\begin{abstract}
The discrepancy model of Stock, Winston, Behrens, and Harper-Marinick (1989) is based on the effects of student expectation of how well they should do, feedback about actual performance, and subsequent student behavior to keep the discrepancy within acceptable bounds. Students can, for example, study to improve their grades if the grades fall below the acceptable level. However, there is another way to explain student performance that does not involve the student's studying or working to achieve better. This perspective says that much academic achievement may be due to how good or poor the student is, and that this can be shown by testing the student in a situation in which no studying is possible. This was done with 68 students who read texts as part of the study and were then tested on what they had read. Their final course grades were compared with their performance on the test of text reading, and it was found that students who made As tended to recall over $70 \%$ of the text, whereas students who made Bs, Ds, Fs, or Ws (withdrew from the course) recalled less than $70 \%$ of the text. Since study of the text material was impossible, the results suggest that the scores on the text reading test were due to some general ability factor, and not always controlled by feedback, discrepancy, studying, or the like.
\end{abstract}

Building on the research of Kulhavy, Yekovich, and Dyer $(1976,1979)$ about feedback and learning, Stock, Winston, Behrens, and Harper-Marinick (1989) have developed a cognitive discrepancy model to explain certain aspects of student performance. Looking at text study time, the authors believe that a continuous feedback loop occurs, which reduces the discrepancy between what the student expects to perform and what feedback shows to be the actual performance. Study time increases when students perform below their expectation.

There is, however, another explanation for student performance that has nothing to do with study time or cognitions about discrepancy. This other explanation is that some students are high in ability and others are low. This ability could be the result of general intelligence, reasoning skills, reading ability, certain kinds of intelligence (Howard Gardner, quoted in Goleman, Kaufman, \& Ray, 1992), or other factors. The prediction from this view would be that the high-ability students achieve well academically and the low-ability students do not. To test this assumption and to distinguish it from the Stock et al. (1989) model, it would be necessary to have a situation in which academic performance was assessed but studying was impossible. This was done in the present study, with the results of text reading compared with grades at the end of the semester.

Address reprint requests to any one of the authors at Department of Psychology, McNeese State University, Lake Charles, LA 70609-1895.

\section{METHOD}

Subjects

The subjects were 68 undergraduate students enrolled in an introduction to psychology class at a state university. The university has open admissions, which means that a wide range of ability is present in the lower division courses such as introduction to psychology, which has mostly freshman and sophomore students.

\section{Procedure}

The instructor informed the students that they could get points on their final grades by participating in the study. The students were told that everyone who participated would get one point added to the final grade. However, they were also told that additional, unspecified amounts of points would be added to the final grade, depending on how well they performed on the test to be given by the experimenters. The better the performance, the more the number of points that would be added. This information should have provided the students with motivation to take the task seriously and try to do well.

The task involved the reading of material passed out by the experimenters, which consisted of five different sections of five and one-half pages from the chapter on social psychology in the students' textbook, which was Gerow (1989). The five different sections were cohesive in and of themselves, but were not in the order in which Gerow had written them. Also, different orders were given to different students, so that cheating would be minimized or impossible. The entire reading time was $25 \mathrm{~min}$, with $5 \mathrm{~min}$ allowed per section; the sections were passed out one at a time. The social psychology chapter had not been covered in the class, so it was material which the student had not previously read. The 30 multiple-choice questions, 6 per section, were taken from the instructor's test manual for Gerow (1989). The students were allowed as much time as they needed to answer the 30 questions (within the limits of the class period, which met for $50 \mathrm{~min}$ ), and most finished in 15-20 $\mathrm{min}$.

The final grades for the course were based on the traditional 10-point spread, with $A=90 \%-100 \%, B=80 \%-89 \%, C=70 \%-79 \%, D=$ 
$60 \%-69 \%$, and $\mathrm{F}<60 \%$. There were also 6 students in the sample who later withdrew from the course and thus obtained a W, for withdrawal.

\section{RESULTS}

All the statistical probabilities reported are two-tailed binomial tests obtained from the table in Siegel (1956) but doubled, since he reports one-tailed probabilities. We looked at students scoring $70 \%$ and above on the 30 -item text reading test versus students who scored below $70 \%$. As expected, the students whose final course grades were A did very well on the 30-item test. All 6 A students scored above $70 \%$ versus none who scored below $70 \%$ correct $(p=.032)$. Five of the A students scored in the $70 \%-79 \%$ range, while one scored in the $80 \%$ range. Also as expected, the $\mathrm{F}$ students did extremely poorly. All 7 of them scored below $60 \%$ on the 30 -item test ( $p=$ .016). Scores below $70 \%$ also predominated among the students whose final grades were $\mathrm{D}, \mathrm{W}$, or B. Of the D students, all 15 scored below $70 \%$ on the text test $(p=.002)$; of the students who later withdrew, 5 of 6 scored below $70 \%(p=.032)$; and of the the B students, 13 of 17 scored below $70 \%(p=.05)$. The only grade group that did not reach the .05 level comprised the $C$ students, of whom 10 scored below $70 \%$ and 7 scored above $(p=.630)$.

\section{DISCUSSION}

The results are consistent with expectation, with the possible exception of the B students, who performed poorly on the text reading test. Otherwise, A students performed well, and students who made a D, $\mathrm{F}$, or $\mathrm{W}$ performed poorly. The findings are consistent with the view that we do not always need to say that studying, feedback, expectations, discrepancy, and so forth, are necessary to explain academic achievement. In this investigation, students could not study for the test, but the results were consistent with the final grades, suggesting that some overall ability factor(s) controlled performance in the text reading test. The results do not disprove Stock et al. (1989), but they suggest that there are different paths to the same endpoint, in this case academic performance. Their cognitive model no doubt explains student performance in some cases, while the ability explanation advanced here explains student achievement, too. Thus, the two explanations can be seen as complementary. At times, people use feedback and decide to increase their studying (or work output) to achieve the level of performance they have come to expect. But, at other times, their ability allows them to achieve, independently of study, increased output, or to satisfy their expectations.
The fact that the B students' performance was not like the A students' but more like the D, F, or W students' is a little puzzling, since we tend to think of a B as a good grade-not as good as an A but in roughly the same domain. However, it may be that the course was graded in a relatively easy fashion, so that getting a B was not all that difficult. Or, it may be that the kind of ability needed to do well on the reading text test has to be very high, so that even students who could attain a B did not possess that ability. Only the A students did.

The fact that the study was done at a university with open admissions may be important. Someone who repeats the study at a more selective school may not get the same results, since Detterman (1986; Detterman \& Daniel, 1989) has shown that it is important to have subjects with a wide range of cognitive or intellectual functioning. Many variables can affect academic performance (Eisenman, in press-a, in pressb), and the use of a wide range of subject ability is more likely to show the true effects than is the use of a sample restricted in range of cognitive or intellectual ability. This is a measurement truism, but it may be especially true for the kind of ability assessed here.

\section{REFERENCES}

Detterman, D. K. (1986, November). Basic cognitive processes predict $I Q$. Paper presented at the meeting of the Psychonomic Society, New Orleans, LA.

Detterman, D. K., \& Daniel, M. H. (1989). Correlations of mental tests with each other and with cognitive variables are highest for low IQ groups. Intelligence, 13, 349-359.

EISENMAN, R. (in press-a). Academic achievement in high school of blacks and whites: A retrospective study of freshmen college students who would not have been admitted without open admissions. The Mankind Quarterly.

EISENMAN, R. (in press-b). Creativity and impulsivity: The deviance perspective. In W. McCown, M. B. Shure, \& J. Johnson (Eds.), The impulsive client: Theory, research, and treatment. Washington, DC: American Psychological Association.

Gerow, J. R. (1989). Psychology: An introduction (2nd ed.). Glenview, IL: Scott, Foresman.

Goleman, D., Kaufman, P., \& Ray, M. (1992). The creative spirit. New York: Dutton.

Kulhavy, R. W., Yekovich, F. R., \& Dyer, J. W. (1976). Feedback and response confidence. Journal of Educational Psychology, 68, 522-528.

Kulhavy, R. W., Yekovich, F. R., \& DYer, J. W. (1979). Feedback and content review in programmed instruction. Contemporary Educational Psychology, 4, 91-98.

SIEGEL, S. (1956). Nonparametric statistics for the behavioral sciences. New York: McGraw-Hill.

Stock, W. A., Winston, K. S., Behrens, J. T., \& Harper-Marinick, M. (1989). The effects of performance expectation and question difficulty on text study time, response certitude, and correct responding. Bulletin of the Psychonomic Society, 27, 567-569.

(Manuscript received June 1, 1992.) 